\title{
THE VOLUME OF THE LUNG DETERMINED BY HELIUM DILU- TION. DESCRIPTION OF THE METHOD AND COMPARISON WITH OTHER PROCEDURES
}

\author{
By GEORGE R. MENEELY AND NOLAN L. KALTREIDER
}

\begin{abstract}
(From the Department of Medicine, School of Medicine and Dentistry, University of Rochester, the Medical Clinics of Strong Memorial and Rochester Municipal Hospitals, Rochester, $N$. Y., and the Heart-Lung Station 1 of the Department of Medicine, Vanderbilt University School of Medicine, Nashville, Tenn.)
\end{abstract}

(Received for publication July 3, 1948)

\section{INTRODUCTION}

The use of the foreign gas, helium, for determination of the pulmonary capacity has been reported previously in preliminary form (1). The present report concerns further experience with this method and comparison of results obtained with results by the Christie method (2) and by the Lassen, Cournand, and Richards modification of the Christie method $(3,4)$ in normal and emphysematous subjects.

Foreign gas methods for measurement of the residual air or mid-capacity are not new. . Van Slyke and Binger (5) employed hydrogen for this purpose. These authors emphasized the danger of explosion with hydrogen-oxygen mixtures and of occasional contamination of hydrogen with arsine. Oxygen dilution methods, especially the method of Christie (2), displaced the foreign gas method. Lassen, Cournand, and Richards $(3,4)$ noted an "Oxygen Storage Effect" which they believed introduced errors in the determination of pulmonary capacity by Christie's method especially in patients with large mid-capacities. To correct this error, they modified the calculation by Christie's method to allow for observed differences in the concentration of nitrogen between the alveolar air and the spirometer circuit at the end of the rebreathing period. McMichael in England (6) modified the Christie method by matching the oxygen consumption of the subject with a controlled inflow of oxygen so that the total volume of the lung and the spirometer circuit remained constant throughout the rebreathing period. He proved this alteration abolished the "Oxygen Storage Effect."

More recently, McMichael (7) reintroduced the foreign gas principle employing hydrogen and the

1 This laboratory was organized under a grant from the Commonwealth Fund. warm wire thermal conductivity katharometer for the analysis. He continued the constant volume feature of his earlier method. The use of a foreign gas with a thermal conductivity quite different from that of oxygen and nitrogen greatly facilitated the determination because it eliminated the separate gas analysis at the end of the rebreathing period. The analysis is continuous with the katharometer and the final concentration is read directly from a meter.

Helium, with a thermal conductivity hardly different from that of hydrogen (Table I), eliminates the danger of hydrogen-air mixtures (which are less now than when first emphasized by Binger and Van Slyke) without sacrifice of the merit of McMichael's method. Since publication of our preliminary article, Behnke (8) has mentioned a method employing helium for the determination of the pulmonary capacity by a "washing out" procedure, which is not related to the method here described except in that helium is used. It is more closely related to the "open" method of Cournand and Richards $(9,10)$.

\section{APPARATUS AND PROCEDURE}

The spirometer circuit is diagrammed in Figure 1. The seven-liter cylindrical spirometer with obliterated internal dead space writes the respiratory tracing on a kymograph drum. The volume of the spirometer may be read from the scale and pointer and, by transfer, from the respiratory tracing itself. The subject is connected to the circuit through a rubber mouthpiece on a three-way valve. The expired air passes vertically through a soda-lime canister for most efficient absorption of carbon dioxide. Oxygen may be added at any desired rate through the diaphragm type flow control and meter on a tank of "medical" oxygen. A blower impels 


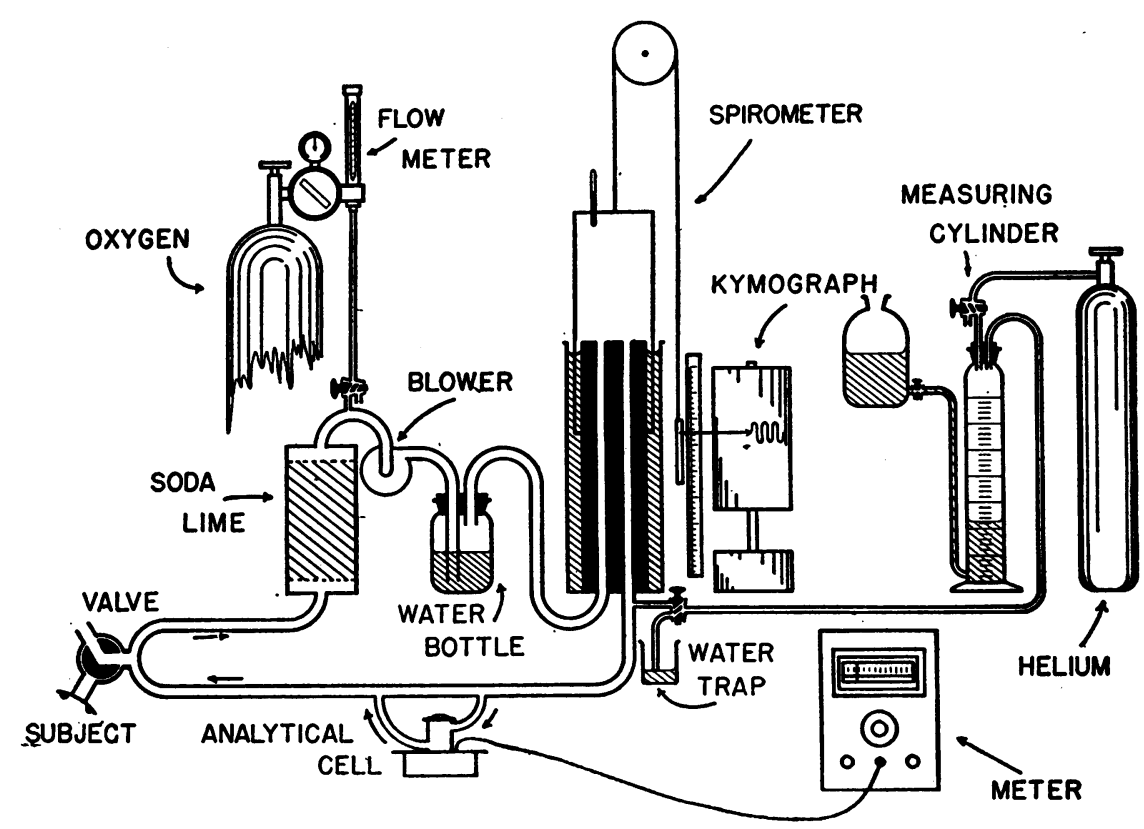

Fig. 1. Spirometer Circuit for Detirmination of the Volume of the Lung USING HELIUM

the expired air through the water bottle which contains many glass beads to break up the bubbles, resaturate the gas mixture, and prevent disagreeable bumping due to large bubbles. Provision is made for the introduction of helium at the spirometer outlet. Part of the return flow shunts through the analytical cell and returns via the cell outlet to rejoin the return stream. The pressure differences in different segments of the circuit are small : slight negative pressure obtains between the sodalime and blower, and positive pressure elsewhere. The soda-lime and the water bottle isolate the blower to a degree, preventing vibration of the air column at the mouthpiece.

The dead space of the circuit was determined by rinsing with air, emptying the spirometer, adding a volume of oxygen and mixing with the blower. The final concentration of nitrogen of the dead space air plus added oxygen was determined on the Van Slyke manometric apparatus and the volume corrected for temperature and barometric pressure. Care must be taken to keep the dead space constant by maintaining the water levels in the spirometer and the water bottle.

The oxygen inflow is adjusted to match the oxygen consumption of the subject by taking a short preliminary respiratory tracing, and setting the valve appropriately. This period also accustoms the subject to rebreathing. Complemental and reserve volume can be recorded at this time. Any desired volume of helium may be measured in the graduate and delivered into the spirometer by directing the flow with the stopcock at the spirometer base into the spirometer and opening the water reservoir valve. Observations indicated that differences in temperature between the graduated cylinder and the spirometer introduced an error of less than $0.5 \mathrm{ml}$. in measurement of the helium added. Since this volume was ordinarily $700 \mathrm{ml}$., this is a negligible error.

The analytical cell ${ }^{2}$ is similar to those used for airplane engine exhaust gas analysis (Figure 2). Complete saturation of the gas mixture is assured by a wet cotton filler in the cell antechamber. When the current through the bridge is maintained constant, and only one component of the gas mixture varies, the indicating meter may be calibrated to indicate the concentration of the gas. For ordinary use, dry cell batteries furnish a suitable cur-

2 Cambridge Instrument Co., New York, N. Y. The design of this cell is such that all four chambers are maintained at the same temperature and the chambers containing the standard gas are at atmospheric pressure. The chambers containing the gas to be measured are at the pressure which obtains in the spirometer circuit which is also atmospheric. Gas enters the cells by diffusion, thus eliminating errors due to flow. 


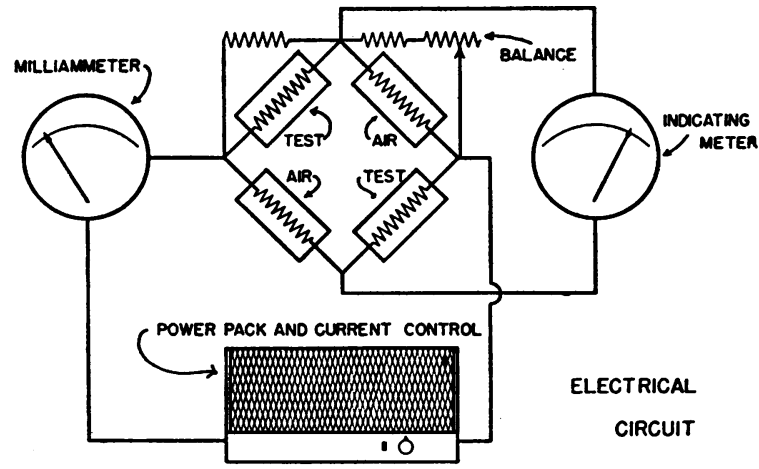

Fig. 2. Diagrammatic Circuit of the Katharometer CeLL

rent source. For the extensive studies reported here, the apparatus was in virtually continuous use and a current-controlled power pack was developed which proved more satisfactory. The circuit of the analytical cell and power pack are shown in Figures 2 and 3 . With a suitable switching circuit the same meter may readily be used to read the current applied to the bridge as well as the deflections due to imbalance of the bridge.

The analytical cell was calibrated over a range of 0 to 15 per cent of helium by adding measured amounts of helium from the graduated cylinder to measured volumes of air in the spirometer circuit.

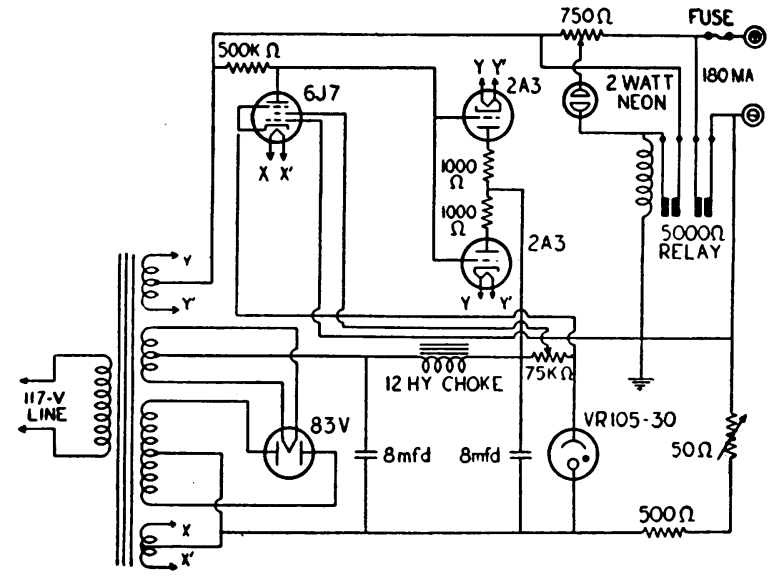

Fig. 3. Circuit of the Current Control Power Pack

Observations during this process, made with the wet and dry bulb thermometers, indicated that unless the water bottle was in the circuit, the saturation of the circulating gas mixtures with water vapor might fall to 70 or even 50 per cent due to - the drying action of the soda-lime. The analytical cell is sensitive to variations in water vapor as to any other gas and thus, for calibration and checking at least, the water bottle is necessary. The water bottle also helps prevent heating due to the blower. Calibration by this means is only absolute if the helium is pure, and in this case, 1.8 per cent

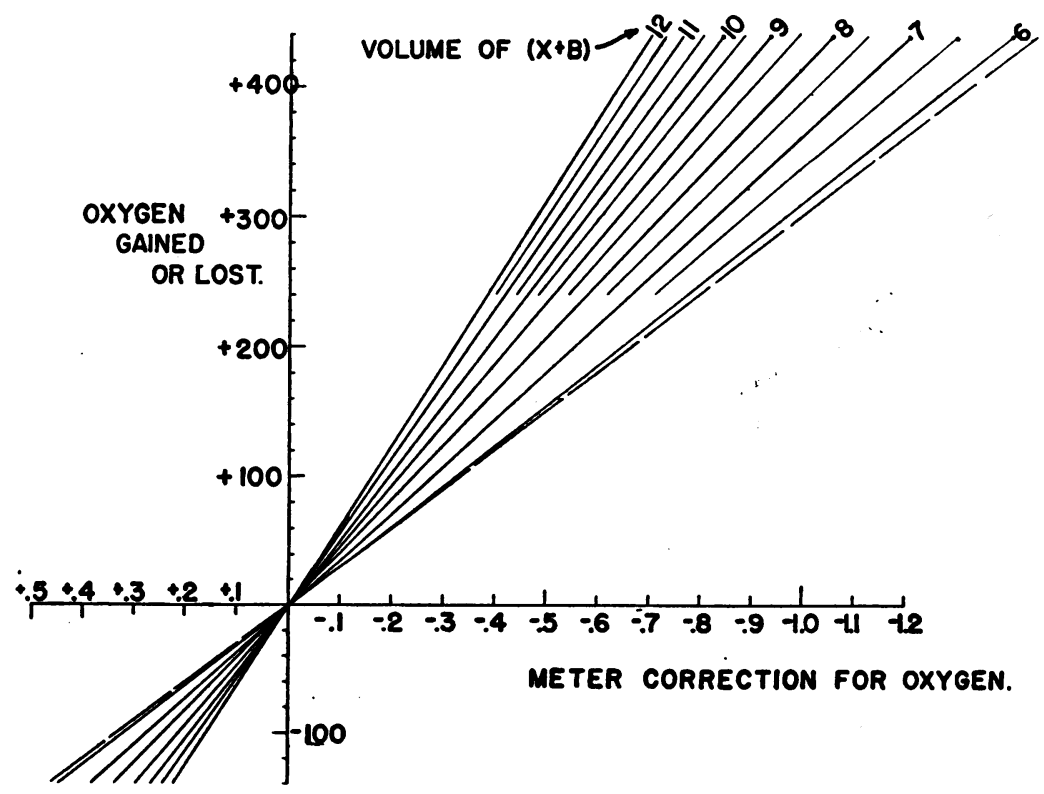

Fig. 4. Graph for Correction of Meter Reading for Changes in OXYgen Concentration 
of "other gases" unspecified were said to be present in the helium. ${ }^{3}$ There were no means at our disposal to investigate this point more fully, but error is not introduced because the analytical apparatus is used in the same manner as it is calibrated, and the major concern is with observed, not absolute values. Thus $700 \mathrm{ml}$. from such a supply contains $687.4 \mathrm{ml}$. of helium.

It proved impossible to match the oxygen consumption of the subject perfectly in every instance and variation in oxygen concentration within the circuit from the beginning to the end of the rebreathing period introduced a small but detectable error, which unfortunately varied depending upon the concentration of helium. Therefore the cell was further calibrated for variation due to oxygen concentration over the range of variation of helium used. This calibration was expressed graphically (Figure 4). A meter correction was obtained by entering this graph with the observed change in oxygen determined from spirometer circuit volume changes and the volume $(\mathrm{X}+\mathrm{B})$ obtained as described below.

\section{ANALYTICAL ERROR}

The accuracy of the helium analyzer was investigated. This cannot be done by the same means as as that used in calibration because, in this case, there is error in the preparation of the gas mixture due to error in measuring the air in the spirometer and error in the measurement of the helium added to the spirometer as well. Accuracy in calibration depends upon averaging a number of determinations over the whole range. To test the reproducibility of the helium analyzer a tank of

TABLE I

THERMAL CONDUCTIVITY OF SEVERAL CASES

ICALORIES PER SECOND PER SOUARE CENTIMETER FOR A THICKNESS OF ONE CENTIMER AND A TEMPERATURE DIFFERENCE OF $1^{\circ}$ CENTIGRADE.)

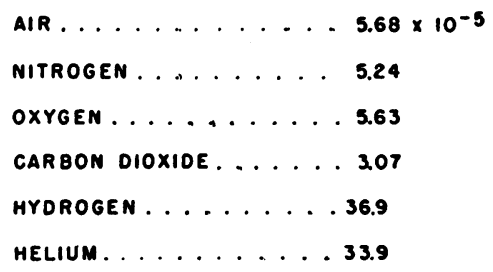

${ }^{3}$ Ohio Chemical Company, "Medical helium."

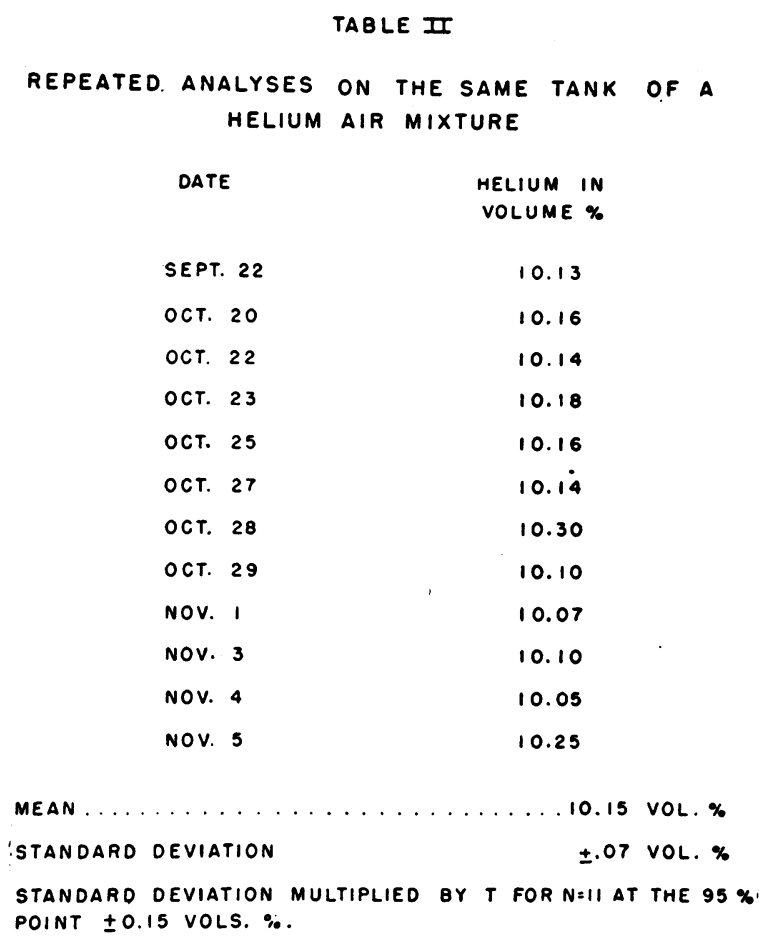

approximately 10 per cent helium in air was obtained.4 This mixture of constant composition was bubbled through water several times and then allowed to flow through the analytical cell which was disconnected from the spirometer circuit for this purpose. The procedure was repeated over a period of several months and the observed concentrations determined with the cell were analyzed statistically (Table II). The mean of these observations which was taken as the "true" concentration of helium in the tank of gas was 10.15 volumes per cent helium with a standard deviation of \pm 0.071 volumes per cent. Then the analytical "error" in 95 per cent of cases would be less than \pm 0.15 volumes per cent or 1.5 per cent (11).

This error was compared with the standard error of the analysis for nitrogen in spirometer mixture and alveolar air samples by statistical analysis of 103 serial pairs of duplicate analyses for nitrogen made on the Van Slyke manometric apparatus during this study. One-half of the difference between duplicates was taken as the deviation from "truth." The standard error was \pm 0.103 volumes per cent. There was no correlation between the magnitude of the error and the concentration of nitrogen. At 80 per cent nitrogen, 95

\footnotetext{
4 Ohio Chemical Company.
} 
per cent of "errors" would lie between \pm 0.26 per cent and at 50 per cent nitrogen between \pm 0.42 per cent. Thus the analysis for helium by the katharometer carries more error than the analysis for nitrogen in the Van Slyke manometric apparatus, when compared by this method.

\section{MIXING TIME}

We investigated the rate at which equilibrium is attained in rebreathing a helium mixture by observing the concentration of helium indicated by the meter at one-minute intervals after turning the subject into the spirometer circuit containing $5,500 \mathrm{ml}$. of 12.5 per cent helium in air while keeping the volume constant by adding oxygen at the rate of the subject's oxygen consumption. In these observations, no allowance was made for lag in the meter which does occur because diffusion must take place from the meter antechamber into the cells in the analyzer block. The results of this investigation are shown in Figure 5. At the end of seven minutes equilibrium has been reached in the group with mid-capacities such that lung plus spirometer volume is less than 8 liters. When this volume is larger, there is a notable difference between the six- and the seven-minute concentrations of helium. When the final lung plus spirometer volume equals 9 or 10 liters, the concentration of

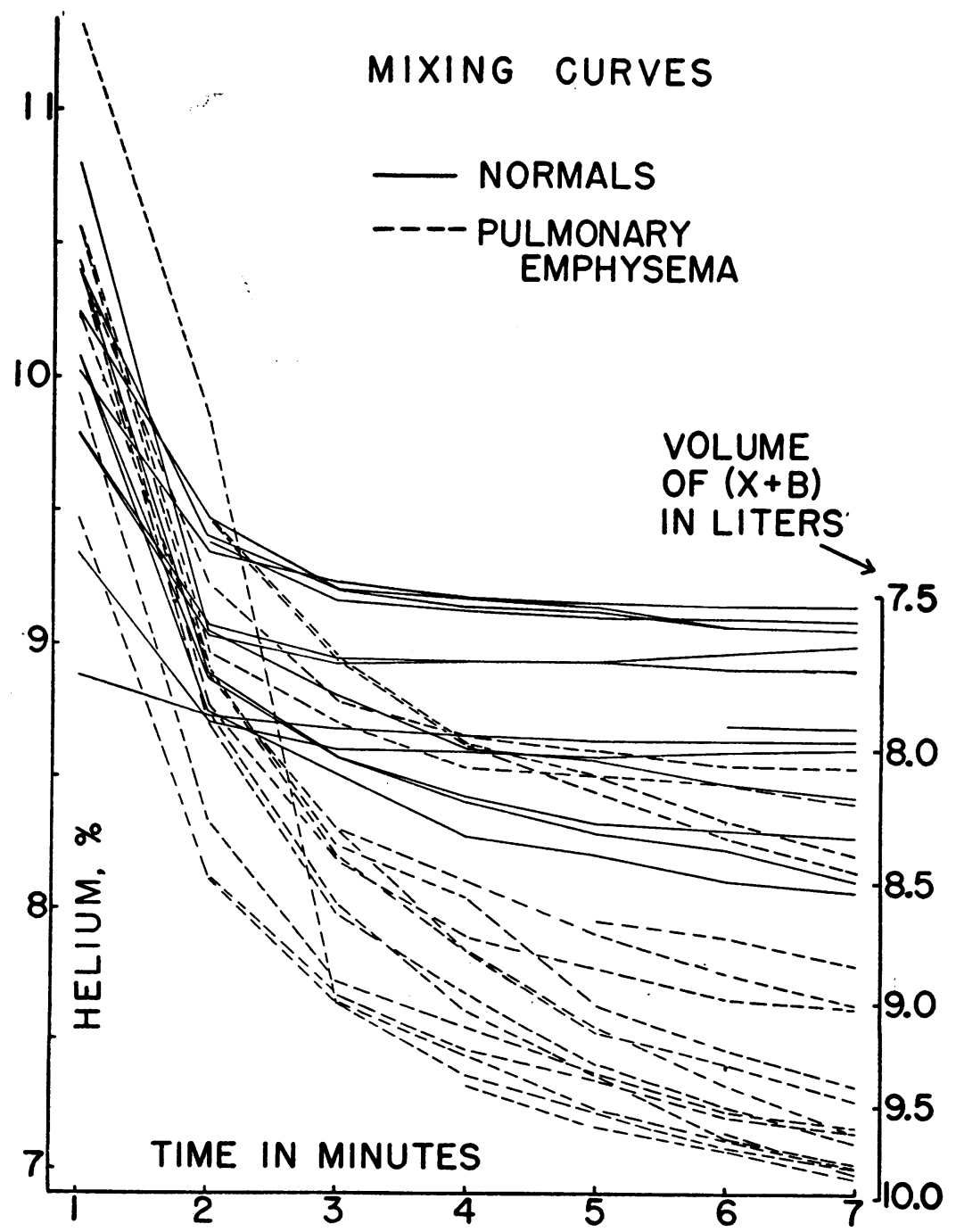

Fig. 5. Concentration of Helium at Intervals of One Minute during Rebreathing a 12.5 Per Cent Mixture of Helium in Air 
helium appears still to be falling at a rate of approximately 0.1 per cent of helium per minute. From these observations we might conclude there is an error due to incomplete mixing of helium in the lung in those subjects with large mid-capacities. However, for practical purposes this is not the case. Comparison was made of seven-minute and ten-minute runs in determining the mid-capacity and there is no important or consistent difference (Table III). McMichael (7) read the hydrogen concentration when the "concentration no longer fell" but in some of our normal subjects there was often a small but detectable change in meter deflection, even after 30 minutes of rebreathing. Other factors, especially leaks, begin to be important in prolonged periods of rebreathing. Spirometer circuits are, after all, only relatively gas-tight, and helium has a very marked tendency to escape, due to its low viscosity and other physical properties. Extra precautions against leakage are especially important when using helium. All joints in our
TABLE III

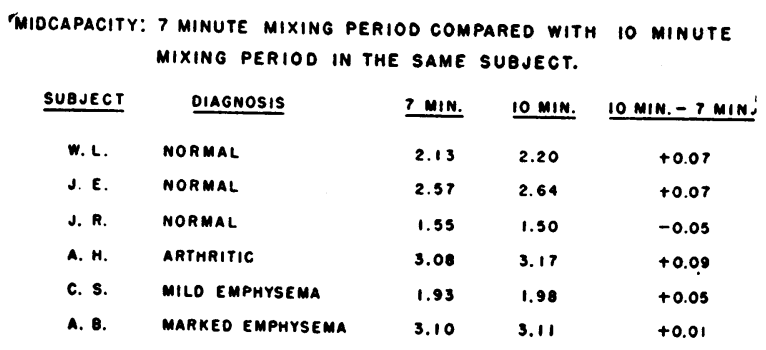

equipment were closely fitted and sealed with Glyptal.

The relation of the data presented in Figure 5 to the pulmonary emptying rate data of Cournand, Baldwin, Darling, and Richards (10) is obvious. It should be remembered, however, that the helium meter reading lags behind the actual concentration changes in the spirometer circuit gases and that these in turn are doubtless different from

5 General Electric Company.

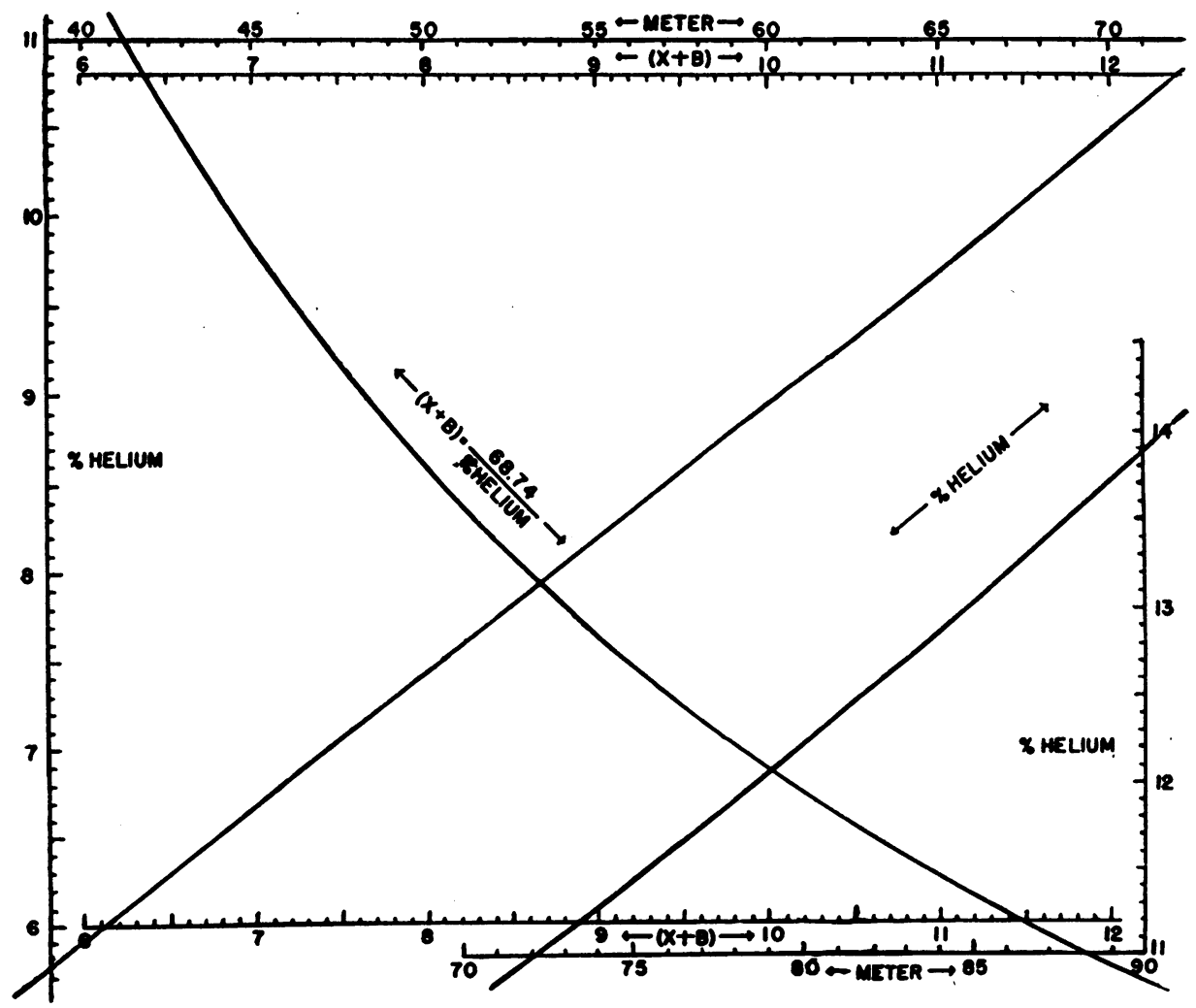

Fig. 6. Graph for Conversion of Meter Reading into Concentration of Helium and to Volume Distribution of Helium 
alveolar helium concentration changes. Despite this, since conditions affecting this relation are relatively constant, much the same conclusions may be drawn from these curves as from the much more laborious pulmonary emptying rate procedure.

\section{REPRODUCIBILITY}

Table IV exhibits 22 pairs of determinations in normal subjects and 13 pairs in emphysematous patients. The difference between duplicates can be used to assess reproducibility of a method (11). The "error" is \pm 0.084 liters in normals and \pm 0.119 liters in emphysematous patients. When these are corrected for sample size (11) it is found that the "standard error" of a single determination will be less than \pm 0.174 liters in normals and less than \pm 0.258 liters in emphysematous patients in 95 per cent of cases. Consequently, the error of the mean of a pair of duplicates will be \pm 0.123 liters and \pm 0.182 liters in normal subjects and emphysematous subjects, respectively, in 95 per cent of cases.

Reproducibility of the method from day to day may be assessed from Table V. The mid-capacity determined in duplicate on different occasions shows deviations of approximately the order of magnitude to be expected from the analysis in the preceding paragraph. "Error" in terms of per
TABLE TT

\begin{tabular}{|c|c|c|c|c|c|c|}
\hline \multicolumn{2}{|c|}{ DUPLICATE } & ING VOLUME & \multicolumn{2}{|c|}{ DETERMINATIONS } & \multicolumn{2}{|c|}{ WITH HELIUM } \\
\hline FIRST & SECOND & DIFFEAENCE & & FIRST & SECONO & Diffenence \\
\hline 1.90 & 1.99 & -.09 & & 2.98 & 2.97 & +.01 \\
\hline 1.70 & 1.79 & -.09 & & 3.23 & 3.13 & +.12 \\
\hline 1.59 & 1.40 & +.19 & & 1.82 & 1.01 & +.01 \\
\hline 1.81 & 1.76 & +.05 & & 2.06 & 2.13 & -.07 \\
\hline 1.56 & 1.61 & -.05 & & 2.56 & 2.58 & -.02 \\
\hline 1.89 & 1.74 & +.15 & & 1.62 & 1.71 & -.09 \\
\hline 2.55 & 2.43 & +.12 & & 3.29 & 3.31 & -.02 \\
\hline 2.20 & 2.65 & -.37 & & 1.51 & 1.71 & -.20 \\
\hline 2.23 & 2.13 & +.08 & & 1.91 & 1.91 & 0 \\
\hline 2.25 & 2.25 & 0 & & 1.90 & 1.63 & +.07 \\
\hline \multirow[t]{3}{*}{2.16} & 2.15 & +.01 & & 1.09 & 1.88 & +.01 \\
\hline & & STAMDARD & ERROR & \multicolumn{2}{|l|}{ \pm 0084} & \\
\hline & & \multicolumn{4}{|c|}{ PATIENTS WITH PULMOMARY EMPHYSEMA } & \\
\hline FInst & SECONO & DIFFERENCE & & FIRST & SECOND & DIFFEREMCE \\
\hline 1.93 & 1.94 & -.01 & & 3.81 & 3.80 & +.01 \\
\hline 3.26 & 2.94 & +.32 & & 3.69 & 3.97 & -.08 \\
\hline 2.96 & 2.71 & +.25 & & 4.13 & 3.90 & +.15 \\
\hline 3.04 & 2.77 & +.27 & & 4.02 & 3.87 & +.15 \\
\hline 3. 17 & 2.90 & +.27 & & 3.66 & 3.67 & -.01 \\
\hline \multirow{3}{*}{$\begin{array}{l}2.42 \\
2.51\end{array}$} & 2.42 & 0 & & 3.90 & 3.97 & -.07 \\
\hline & 2.45 & +.06 & & & & \\
\hline & & STANDARD & ERROR & \pm 0.119 & & \\
\hline
\end{tabular}

cent for the helium method appears to be less than \pm 6 per cent in 95 per cent of cases when the mean of duplicate determinations is used, whether the subjects are normal or emphysematous.

\section{COMPARISON WITH OTHER METHODS : PROCEDURE}

The Christie procedure (2) and the modified Christie method of Lassen, Cournand and Richards

TABLE I

REPEATED DETERMINATIONS WITH HELIUM ON DIFFERENT DAYS

\begin{tabular}{|c|c|c|c|}
\hline & DATE & MID-CAPACITY, LITERS & DEVIATION FROM MEAN \\
\hline $\begin{array}{l}\text { T.A. FEMALE } \\
\text { NORMAL }\end{array}$ & $\begin{array}{l}\text { NOV. } 22 \\
\text { OEC. } 27\end{array}$ & $\begin{array}{l}1.94 \\
1.75\end{array}$ & $\begin{array}{l}+0.095 \\
-0.095\end{array}$ \\
\hline $\begin{array}{l}\text { J.A. ARALE } \\
\text { NORMAL }\end{array}$ & $\begin{array}{l}\text { OEC. } 21 \\
\text { OEC. } 28\end{array}$ & $\begin{array}{l}1.50 \\
1.79\end{array}$ & $\begin{array}{l}-0.145 \\
+0.145\end{array}$ \\
\hline $\begin{array}{l}\text { G.M. MALE } \\
\text { MORMAL }\end{array}$ & $\begin{array}{l}\text { NOV. } \\
\text { APRIL } 23\end{array}$ & $\begin{array}{l}1.61 \\
1.81\end{array}$ & $\begin{array}{l}-0.10 \\
+0.10\end{array}$ \\
\hline $\begin{array}{l}\text { E.M. FEMALE } \\
\text { NORMAL }\end{array}$ & $\begin{array}{l}\text { maY } 16 \\
\text { MAY is }\end{array}$ & $\begin{array}{l}2.46 \\
2.49\end{array}$ & $\begin{array}{l}-0.015 \\
+0.015\end{array}$ \\
\hline $\begin{array}{l}\text { B.M. MALE } \\
\text { NORMAL }\end{array}$ & $\begin{array}{l}\text { SEPT. I } \\
\text { SEPT. } 2 \\
\text { SEPT. } 7\end{array}$ & $\begin{array}{l}2.19 \\
2.25 \\
2.16\end{array}$ & $\begin{array}{l}-0.01 \\
+0.05 \\
-0.04\end{array}$ \\
\hline $\begin{array}{l}\text { W.L. MALE } \\
\text { NORMAL }\end{array}$ & $\begin{array}{l}\text { DEC. } 4 \\
\text { DEC. } 8\end{array}$ & $\begin{array}{l}2.06 \\
2.13\end{array}$ & $\begin{array}{l}-0.035 \\
+0.035\end{array}$ \\
\hline $\begin{array}{l}\text { E.H. MALE } \\
\text { NORMAL (ARTHRITIC) }\end{array}$ & $\begin{array}{l}\text { NOV. } 18 \\
\text { DEC. } 10\end{array}$ & $\begin{array}{l}2.97 \\
3.19\end{array}$ & $\begin{array}{l}-0.11 \\
+0.11\end{array}$ \\
\hline $\begin{array}{l}\text { A.8. FEMALE } \\
\text { MARKED EMPHYSEMA }\end{array}$ & $\begin{array}{l}\text { DEC. } 17 \\
\text { OEC. } 21\end{array}$ & $\begin{array}{l}3.26 \\
2.94\end{array}$ & $\begin{array}{l}+0.16 \\
-0.16\end{array}$ \\
\hline $\begin{array}{l}\text { W.D. MALE } \\
\text { EMPPHYSEMA }\end{array}$ & $\begin{array}{l}\text { APRIL 15 } \\
\text { APRIL 16 } \\
\text { APRIL 21 }\end{array}$ & $\begin{array}{l}2.90 \\
2.83 \\
3.03\end{array}$ & $\begin{array}{l}-0.02 \\
-0.09 \\
+0.11\end{array}$ \\
\hline
\end{tabular}


$(3,4)$ were carried out in the usual way. After these determinations were complete, the subject rested while the oxygen flow valve was adjusted to allow an inflow of oxygen into the spirometer circuit equal to his observed oxygen consumption. Turning off the stopcock between the oxygen tank flow control and the spirometer circuit (see Figure 1) stops the oxygen flow without disturbing the flow rate setting. The spirometer circuit was again well rinsed with room air, and the helium meter turned on. With the current through the bridge set at the standard value, the meter was adjusted to indicate zero with the balancing resistance on the cell (Figure 2). The spirometer circuit was brought to a volume of $4,800 \mathrm{ml}$. with air, and $700 \mathrm{ml}$. of helium were added from the graduated cylinder. Two hundred $\mathrm{ml}$. of oxygen were then added to bring the oxygen concentration back to that of room air. As the blower mixed these gases, the helium meter deflected to indicate a concentration of $\mathbf{1 2 . 5}$ per cent helium, confirming the proper functioning of this instrument. Now the subject was allowed to rebreathe for seven minutes. Oxygen flow into the circuit at the previously determined rate was started simultaneously with turning the valve directing the subject into the spirometer circuit. At the end of rebreathing, the subject was turned back to room air and the oxygen flow stopped simultaneously. The subject was disconnected; the temperature was recorded. A few moments were allowed for absorption of carbon dioxide while circulation by the blower continued. Then the final meter reading was recorded. The relation of the initial and final lines on the kymograph tracing to the spirometer scale were recorded. These then constitute a record of the volume changes of the bell. This whole procedure was repeated after a suitable rest period.

Finally, the subject was again connected to the spirometer circuit, and while the kymograph recorded the respiratory tracing, the subject made several maximal expirations with periods of quiet breathing between, then several maximal inspirations. From this tracing the complemental air and reserve air were measured.

\section{Calculations and corrections}

The mid-capacity by the original Christie method was calculated from the equation:

$$
M C=\frac{N(D+O)-(0.791 D+C)}{(0.791-N)}
$$

where $\mathrm{MC}=$ mid-capacity

$\mathrm{D}=$ volume of dead space in $\mathrm{ml}$.

$\mathrm{O}=$ volume of $\mathrm{O}_{2}$ in ml. added originally minus $\mathrm{O}_{2}$ absorbed.

$\mathrm{N}=$ per cent concentration of nitrogen in spirometer at end divided by 100 .

$\mathrm{C}=$ correction for nitrogen in the oxygen added originally for respiratory quotient and for nitrogen excreted from the body during rebreathing.

The modification of Lassen, Cournand and Richards was calculated from this equation:

$$
M C=\frac{N(D+O)-(0.791 D+C)}{\bar{a}-\bar{p}}
$$

where $\overline{\mathrm{a}}=$ per cent nitrogen concentration in alveolar air before rebreathing divided by 100 .

$\overline{\mathrm{p}}=$ per cent nitrogen concentration in alveolar air after rebreathing divided by 100 .

Calculation of the mid-capacity by helium required first that the meter reading be corrected for gain or loss of oxygen observed in the respiratory reading (Figure 4). With this corrected value the following equation could be used although graphic methods were actually employed in practice:

$$
\mathrm{MC}=\frac{\mathrm{QHe}}{\mathrm{CHe}}-\mathrm{SV}
$$

where: $\mathrm{SV}=$ spirometer circuit volume, i.e., dead space plus spirometer bell volume at expiration.

$\mathrm{QHe}=\mathrm{ml}$. helium added before rebreathing.

$\mathrm{CHe}=$ final helium per cent concentration divided by 100 . This concentration can be obtained from calibration graph entered with the meter reading corrected for changes in $\mathrm{O}_{2}$ concentration (Figure 6).

Since 0.700 liters of tank gas containing 0.6874 liters of $\mathrm{He}$ are always added, the numerator of the above fraction is fixed.

All these mid-capacities must be corrected for temperature, water vapor, and barometric pressure. For this the customary equation was used:

$$
\mathrm{MC} \text { cor. }=\mathrm{MC} \text { obs. } \times \frac{(760-\mathrm{Pt})}{(760-45)} \times \frac{(273-37)}{(273-\mathrm{T})}
$$

where $\mathrm{MC}$ cor. $=$ mid-capacity corrected for temperature and barometric pressure.

MC obs. = mid-capacity observed.

$\mathrm{T}=$ final spirometer temperature in degrees C.

$\mathrm{Pt}=$ partial pressure of water vapor in $\mathrm{mm}$. of $\mathrm{Hg}$ for $\mathrm{T}$.

$45=$ partial pressure of water vapor at body temperature $37^{\circ} \mathrm{C}$.

In actual practice graphic methods as introduced by McMichael (6) were used. Figure 6 is a composite graph of the relation between the meter reading, the concentration of helium, and the volume in which 0.6874 liters of helium must be distributed if the concentration is as indicated. The upper horizontal line of the graph was entered with the meter reading and a perpendicular dropped from this reading to the helium concentration line. From this 
point, by reading horizontally to the helium scale, the concentration of helium could be obtained. At the point where this horizontal intercepted the curved line denoting the volume of distribution of helium, one may read vertically to the horizontal scale of values for $(X+B)$, which represents the total volume of lung and spirometer system. However, this reading is in error due to variation in oxygen concentration. The observations of variation of meter reading for variation in oxygen concentration were converted into a graph in terms of oxygen gained or lost for various values of $(X+B)$ : that is, at various concentrations of helium (Figure 4). The tentative value of $(\mathrm{X}+\mathrm{B})$ together with the oxygen gained or lost was used to enter Figure 4 to obtain a meter correction for oxygen. With this new corrected meter reading, the composite graph (Figure 6) was again entered, reading vertically from the meter scale to the helium concentration line, then horizontally to the volume of $(X+B)$ curve, thence vertically to the scale of $(X+B)$. $(X+B)$ corresponds to $\frac{\mathrm{QHe}}{\mathrm{CHe}}, \mathrm{X}$ corresponds to mid-capacity and $\mathrm{B}$ corresponds to $\mathrm{SV}$, the spirometer circuit volume.

The helium mid-capacity requires further correction. The dead space of the mouthpiece and valve was $38 \mathrm{ml}$. Assuming a respiratory quotient of average value, 0.8 , and 2 liters for the mid-capacity, there is an apparent increase of $30 \mathrm{ml}$. in the mid-capacity due to differences in concentration of inert gases between the lung and the spirometer system. In our earlier report (1) we stated that $10 \mathrm{ml}$. of helium were absorbed by the body during the period of rebreathing. Extension of the experiments by which we arrived at this figure cast doubt upon their validity. Ten $\mathrm{ml}$. of helium distributed in a volume of approximately 8 liters of lung plus spirometer gas is not easy to find by analysis for differences in concentration, for at a helium concentration of around 8.5 volumes per cent, in this 8-liter volume, a $10-\mathrm{ml}$. change in the quantity of helium would result in a change of only 0.125 volumes per cent or 1.56 per cent in the concentration. Since the error of analysis is of the same order of magnitude, determination of changes in concentration of helium after equilibrium between lung and spirometer has been reached cannot be expected to show losses of this small magnitude reliably. As previously mentioned, methods of accurate absolute analysis for helium in the presence of other gases were not available to us. Proper investigation of this point remains for the future. Some helium must inevitably be absorbed during rebreathing, and if it were much more than $10 \mathrm{ml}$., we could - have detected it with some accuracy. Therefore we have continued to subtract $110 \mathrm{ml}$. from the observed midcapacity which is the amount attributable to a loss of $10 \mathrm{ml}$. of helium with an average mid-capacity of 2 liters. It is then to be remembered that all the mid-capacities by helium are made $110 \mathrm{ml}$. smaller by this rather arbitrary correction. In practice, $180 \mathrm{ml}$. were subtracted as the rounded total of the three corrections: mouthpiece, R.Q., and helium absorption. The mouthpiece volume correction is applied to the other calculations also, and the difference in inert gas between lung and spirometer due to R.Q. is also written into the equation (Q.V.).

\section{RESULTS OF COMPARISON WITH OTHER METHODS}

The original Christie (2) mid-capacity method and the Lassen, Cournand and Richards $(3,4)$ modification of the original Christie method are compared with the new helium method in ten normal subjects and eight patients with pronounced pulmonary emphysema in Table VI. Each determination was done in duplicate. There is less variation between duplicates by the helium method than by either of the other two methods, not only in normals but also in patients with emphysema. From the last two lines of Table VI it is seen that in the normals the volume determined with helium is virtually always smaller than the volume determined by the other two methods by an amount of approximately $200 \mathrm{ml}$. and $100 \mathrm{ml}$., respectively. In this connection it should be recalled that the rather arbitrary correction for helium taken up by the body is of this same order of magnitude. We have no objective proof of the absorption of helium, although we know from purely physical considerations that some must take place.

It may be observed that differences between the original Christie and the corrected Christie, while fairly consistent in the normal subjects, are not at all so in those patients with emphysema, although according to the "oxygen storage" concept the difference should be more marked in this group. The original method gives values in normals consistently higher by about $1 / 10$ liter. However, in the emphysematous patients no such consistency is observed and indeed the mean difference is in the opposite direction. The explanation of this inconsistency in the emphysematous patients is found in the variable relation of their initial and final alveolar air samples to outside air and to final spirometer nitrogen, respectively. It was our opinion that the corrected mid-capacity did not offer any advantage over the original method in pathological subjects despite the theoretical advantages described for it. In a personal communication the authors of the corrected method informed us that they now prefer their open method (9).

\section{CONCLUSIONS}

The principal advantage of this method of determining mid-capacity is the speed with which determinations may be carried out, together with evidence indicating a higher degree of reproducibility. 


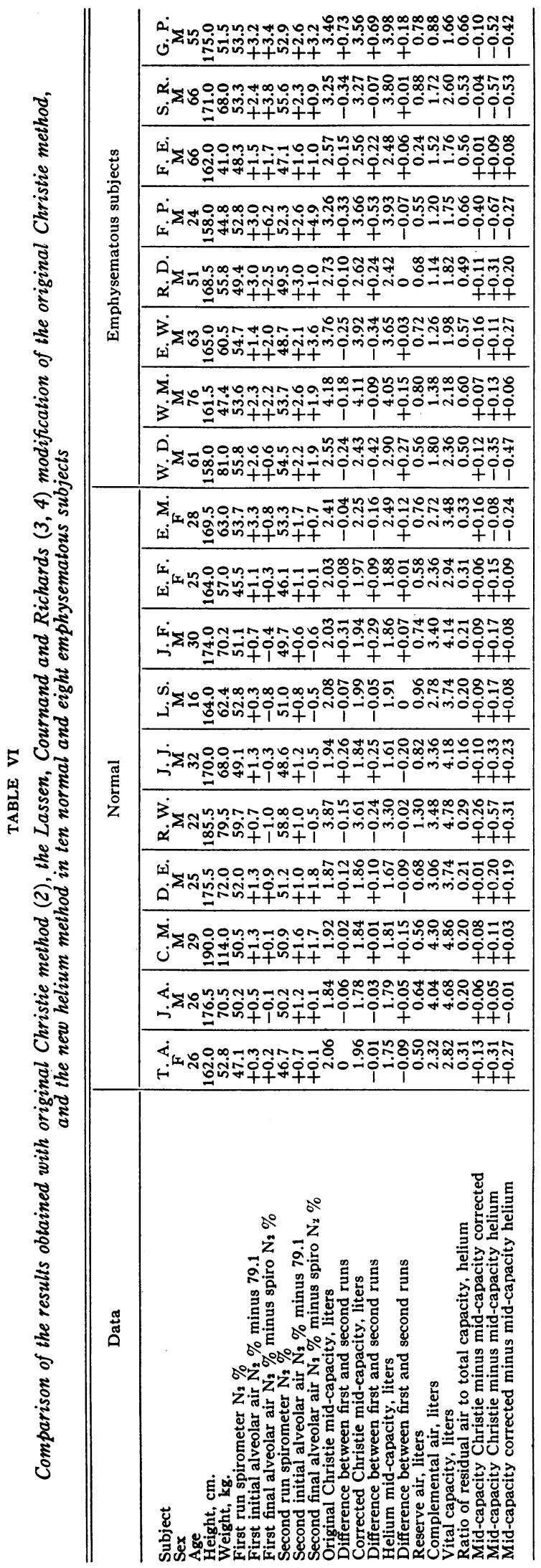


The method has been employed in the CardioRespiratory Laboratory of the University of Rochester for several years with very satisfactory results. The determination of mid-capacity is growing in clinical recognition, particularly in relation to the diagnosis of pulmonary emphysema. The facility with which the determination can be made will make possible broader application of this valuable test. It is evident that a number of steps might well be taken to simplify and further improve the method described. Particular attention ought to be devoted to reduction of spirometer circuit volume and increases in accuracy might be secured by employing higher concentrations of helium.

\section{SUM MARY}

1. A full description of a new method for the determination of the volume of the lung has been presented.

2. Graphic methods were employed for rapid solution of the calculations involved.

3. Data are presented to permit critical evaluation of the method as to reproducibility and as to comparison with two other methods.

4. The rapidity and accuracy of this new method recommend it for clinical application.

\section{BIBLIOGRAPHY}

1. Meneely, G. R., and Kaltreider, N. L., Use of helium for determination of pulmonary capacity. Proc. Soc. Exper. Biol. \& Med., 1941, 46, 266.
2. Christie, R. V., The lung volume and its subdivisions. J. Clin. Invest., 1932, 11, 1099.

3. Lassen, H. C. A., Cournand, A., and Richards, D. W., Jr., Distribution of respiratory gases in closed breathing circuit. I. In normal subjects. J. Clin. Invest., 1937, 16, 1.

4. Cournand, A., Lassen, H. C. A., and Richards, D. W., Jr., Distribution of respiratory gases in closed breathing circuit. II. Pulmonary fibrosis and emphysema. J. Clin. Invest., 1937, 16, 9.

5. Van Slyke, D. D., and Binger, C. A. L., Determination of lung volume without forced breathing. J. Exper. Med., 1923, 37, 457.

6. Herrald, F. J. C., and McMichael, J., Determination of lung volume: simple constant volume modification of Christie's method. Proc. Roy. Soc., London, S.B., 1939, 126, 491.

7. McMichael, J., A rapid method of determining lung capacity. Clin. Sc., 1939, 4, 167.

8. Behnke, A. R., Jr., Feen, B. G., and Welham, W. C., The specific gravity of healthy men. J. A. M. A., 1942, 118, 495.

9. Darling, R. C., Cournand, A., and Richards, D. W. Jr., Studies on the intrapulmonary mixture of gases. III. An open circuit method for measuring residual air. J. Clin. Invest., 1940, 19, 609.

10. Cournand, A., Baldwin, E. DeF., Darling, R. C., and Richards, D. W., Jr., Studies on intrapulmonary mixture of gases. IV. Significance of the pulmonary emptying rate and a simplified open circuit measurement of residual air. J. Clin. Invest., 1941, 20, 681.

11. Mainland, D., The Treatment of Clinical and Laboratory Data. Oliver and Boyd Ltd., Edinburgh, 1938 , p. 139. 